\title{
Legal and Institutional Framework on Training of Civil Servants in Albania - Developments over the Years
}

\author{
PhD candidate Merita Malile
}

Universiteti Mesdhetar i Shqipërisë (UMSH)

email: meriona2006@yahoo.com

PhD Iris Petrela

University of Tirana (UT)

email: i.petrela@gmail.com

Doi:10.5901/jesr.2014.v4n2p208

\section{Abstract}

The civil service system is relatively new in Albania. Its origin dates back to 1996, when the civil service was for the first time established and regulated by law. The law aimed to regulate the work relations of the employees of the public administration, central and local, at the same time institutions that function based on an annual budget provided by the State. In 1998 was adopted the Constitution of the Republic of Albania, which includes a specific provision on civil servants. Following the entrance into force of the Constitution, a new law on civil servants was adopted in 1999, which guaranteed the protection of civil servants rights as employees of public administration from State institutions in the role of the employee and the civil service law established specific protection mechanisms. According to the Civil Service Law of 1999 the recruitment process is based totally on individual merits and is carried out through an open competition. Among the rights of civil servants is the right to be trained for the tasks they are expected to perform even in probation period. In addition, civil servants should be offered continuous and paid training activities in connection to their job position. The institution that offered such training and was responsible for the initial and continuous training of civil servants was TIPA, under the supervision of the Department of Public Administration. In June 2006, Albania signed in Luxemburg a Stabilization and Association Agreement (SAA) with the EU members. The co-operation between the EU and Albania in the framework of the SAA shall focus on the implementation of transparent and impartial procedures of recruitment, human resource management, and career development in the public service both in the central and local public administration. As part of the national plan for the implementation of the SAA in public administration a new civil service law was approved in May 2013, which became effective in February 2014. The new law provides for a School of Public Administration which will provide better quality training to civil servants aiming at increasing the skills of civil servants of various categories. Thus, this paper will present an historical overview of developments in civil service in Albania by focusing on the training element of civil servants, its achievements over the years, but also problematic issues observed. The authors will analyze the legal, sub legal and institutional framework in place and will present their conclusions by making reference to regulation of training activities for civil servants in some European countries legislation with a longer legacy in civil service. Furthermore, the authors will present their opinion on how should the legal framework should be improved in this area.

Keywords: civil servant, training, Training Institute of Public Administration (TIPA), Albanian School of Public Administration (ASPA), civil service law, training curricula.

\section{Introduction}

The civil service system is relatively new in Albania. Its origin dates back to 1996, when the civil service was for the first time established and regulated by law. ${ }^{1}$ This law aimed at regulating the work relations of the employees of the public administration, central and local, at the same time institutions that function based on an annual budget provided by the State. For the rest of work relations and categories of employees other than civil servants the Code of Labour of the Republic of Albania was applied. Based on the 1996 law the categories of civil service included the political office holders. In 1998 was adopted the Constitution of the Republic of Albania, which includes a specific provision on civil servants. ${ }^{2}$ The terminology used in the Constitution differs from that of the law adopted in 1996. This is understandable

\footnotetext{
1 Law no.8095, dated 21.03.1996, "On civil service in the Republic of Albania"

2 Article 107, Law no.8417, dated 21.10.1998 "Constitution of the Republic of Albania"
} 
given that the 1996 law on civil service was adopted at a time when no consolidated text named as Albanian Constitutional existed. Instead, several laws issued at different time periods were recognised as the Albanian Constitutional Package and in which civil servants were not mentioned at all. ${ }^{3}$ As a general rule of legislative technique, the terminology of the Constitution must be respected when laws and bylaws about specific areas are issued.

\section{Training Institute for Public Administration}

The previous Civil Service Law of $1999^{4}$ and also the new law provide that civil servant should be trained for his respective job on a regular basis, at the expense of the State. For the purpose of offering training to civil servants it was established the Training Institute of Public Administration through a Council of Ministers Decision. ${ }^{5}$ The Training Institute of Public Administration (TIPA) has been created as an institution under the supervision of the Council of Ministers. Its mission was to support the improvement and reform of a sustainable and professional civil service through qualitative and comprehensive training and professional development. The Institute ensures the professional training of the civil servants, which includes:

a) Training during the probation period;

b) Training for career development;

c) Training, in cases of changes in the job position criteria;

d) Specialized training on performing specific duties (tailored training).

\section{Vocational Training Planning at Central and Local Levels}

The creation of training curricula and offering of qualifications are, on the one hand, a basic right of civil servants and, on the other, one of the obligations of the employer toward it employees. This important process should be carefully planned, based on different approaches that mirror the careful identification of training needs of these employees. It should be underlined that the proper performance appraisal could provide very useful and detailed input for planning and implementing training for each civil servant.

In a study of the Council of Europe in Albania it is noticed that several important actors are involved in the process of assessing training needs of civil servants. Their direct supervisors seem to play a dominant role, as the most active in the process, in $78 \%$ of districts and $61 \%$ of municipalities. ${ }^{6}$ According to the statistics of the Report of the CoE in Albania, the human resources units; $67 \%$ - districts and $33 \%$ - municipalities seem to cooperate closely with the respective civil servants and provide valuable input into training needs assessment. Despite the positive complementary efforts toward training needs assessment, again, according to this Report, the planning of training needs is poorly designed, because annual training plans are reported as being designed only in $33 \%$ of the regions and only in $27 \%$ of the municipalities. When it comes to the cooperation with the Training Institute for Public Administration (TIPA) the situation is reported to be even worse; only $16 \%$ of the municipalities and none of the regions resulted to have submitted the annual plan to the TIPA. ${ }^{7}$ A similar negative situation has been observed in budget planning for training. Thus, this Report, as overall evaluation of the vocational training for civil servants states:

"It is a segmented and chaotic process and the lack of formal planning and accompanying budget is evident."

\footnotetext{
${ }^{3}$ Law no.7941, dated 29.04.1991, "On main Constitutional provisions", abrogated by Law no.8417, dated 21.10.1998 "Constitution of the Republic of Albania"

${ }^{4}$ Article 20 of the Law no.8549, dated 11 November 1999 "On civil servant's status" and Article 38 of the Law no.152/2013 "On civil servant"

${ }^{5}$ Council of Ministers' Decision no.315, dated 23 June 2000.

${ }^{6}$ Report of the Council of Europe in Albania "The National Assessment of Local Government Units' Capacities to Implement the New Law "On Civil Servant", September 2013. This report is prepared by the Project on "Strengthening Local Government Structures and Cooperation of Local Elected Representatives in Albania - Phase II (2012-2015)", implemented by Council of Europe, with support of Swiss Agency for Development and Cooperation (SDC), pg.50

${ }^{7}$ Ibid.
} 


\section{The Commitments of Albania in the Framework of the Stabilization Association Agreement with the European Union}

In June 2006, Albania signed in Luxemburg a Stabilization and Association Agreement (SAA) with the EU members. ${ }^{8}$ This Agreement consists of four pillars: political dialogue and regional co-operation, trade provisions concerning the progressive liberalization of exchanges until a free trade zone is established between the parties, community freedoms, and finally, co-operation in fields of priority, especially in justice and internal affairs.

Article 111 of Chapter VIII of the SAA "Cooperation Policies" focuses on public administration. The objective of this article is to ensure the development of an effective and responsible public administration in the country, which would support the practical application of the rule of law. Thus, the co-operation between the EU and Albania in the framework of the SAA shall focus on the implementation of transparent and impartial procedures of recruitment, human resource management, and career development in the public service both in the central and local public administration.

The signing of the SAA is only the first step towards the reform of the public administration, so that Albanian public administration standards meet the requirements of the European Union. This process requires professional civil servants, who can guarantee independence, integrity, transparency, and adhere to the principle of public services. These civil servants deserve at the same time to have their rights respected, protected and redressed by the relevant state bodies, when they are violated.

The Progress Reports on Albania ${ }^{9}$ over the years note, among others, that [The Civil Service Law regulating public administration is in place, but it is not applied systematically. ... The absence of sound accountability mechanisms in public administration increases the opportunities for bypassing established procedures. ... Frequent replacements of civil servants are undermining the independence of the civil service and increase the opportunities for bribery of public officials. Overall, the public administration continues to stabilise, but the lack of transparency and accountability in appointments is endangering its independence.] Thus, more commitment and concrete work is required by the Albanian State institutions so that the Albanian public administration be considered sustainable and professional which would count for recognizing Albania the status of the EU candidate country.

\section{Establishment of the Albanian School of Public Administration Under a New Law on Civil Service}

Until May 2013 there have been two previous unsuccessful attempts to amend the Civil Service Law of 1999, but due to the fact that this kind of law requires a qualified majority to be approved the proposed amendments remained only proposals. It has been foreseen under the short term priorities of Albania to amend the Civil Service Law of 1999 during the years 2005-2006.10 The third attempt for legal changes in the civil service field started in late 2010 and continued during the year 2011. A new draft law on civil service in Albania was prepared based on the legal assistance of SIGMA ${ }^{11}$ and this draft has been submitted to the Parliament in September 2012 while the draft was passed in plenary session of the Parliament only on 30 May 2013, one month before the general election in Albania when wide consensus was reached among political parties represented in the Parliament. ${ }^{12}$ When passed in the plenary session, upon proposal of the opposition forces of that time the $1^{\text {st }}$ October 2013 was proposed to be the date for the entrance into force of this law, while the rest of the provisions were passed quickly without debate by the members of the Parliament. The approval of this law was considered a success by all political parties represented in the Parliament as a step forward for the integration of the Albania into the European Union and as a fulfillment of one of the main priorities that European Union had imposed on Albania.

The new Civil Service Law of 2013 provides for the establishment of the Albanian School of Public Administration (ASPA). As a matter of fact, the previous Council of Ministers established this School in April 2013 through a Council of

\footnotetext{
${ }^{8}$ Entire text of the SAA and more information on it can be found at www.mie.gov.al

${ }^{9}$ For illustration purposes an excerpt of the 2008 Progress Report on Albania - chapter on "Public Administration"; Rapporteur for Albania Mr. Libor Rouček

10 "Plan of the Government of Albania for the Approximation of Legislation and Implementation of the Stabilisation and Association Agreement" approved by the Council of Ministers through Decision no. 314, dated 13.05.2005. It is related more specifically to the observation of Article 110 of the Stabilisation and Association Agreement

11 SIGMA (Support for Improvement in Governance and Management) is a joint initiative of the European Union and the OECD.

12 The new Law on Civil Service approved on 30 May 2013 was published in the Official Journal on 7 June 2013.
} 
Ministers' Decision. ${ }^{13}$ Thus, currently this School exists, but comprises as personnel only the personnel inherited by its predecessor Training Institute of Public Administration (TIPA). The School has new premises, but it is in a stalemate due to the fact that the new civil service law has not be effective until 26 February 2014 when the Constitutional Court's Decision on the effectiveness of the new Civil Service Law of 2013 was published in the Official Journal and the necessary secondary legislation for the functioning of the School has only been approved by the current Council of Ministers in March 2014. Moreover, its training curricula should be revised and eventually approved in accordance with this School's mission and vision for various categories of civil servants. The establishment of the ASPA was listed among the objectives of the Cross-Cutting Strategy for the Public Administration Reform 2009-2013. ${ }^{14}$ Currently, it exists as a subordinate structure of the Minister of Interior as a central public institution, with headquarter in Tirana. ${ }^{15}$ In fact, following recent legal initiative of the Council of Ministers this structure is proposed to be a subordinate one to the newly created Ministry of Innovation and Public Administration. The ASPA will have administrative and academic autonomy and its aim is the vocational training of civil servants, as well as any other individual, national or international, who is not part of the civil service and that meets the required criteria. By vocational training is understood the in-depth training program of candidates for the category of the top-level management civil servants, members of the Top-level management Corps and the continuous vocational training program for civil servants, as well as any other individual outside the service. ${ }^{16}$ This School will have its own budget which will be determined as a separate budget line under the budget of the Ministry of Interior (if the Council of Ministers' initiative for legal amendments to the new CSL will be approved it will pass as a subordinate structure of the Ministry of Innovation and Public Administration). This School will have a director for leading its everyday activities and a governing board of 9 members. The Board will be composed of representatives and senior officials from line ministries, local government, DoPA, universities, civil society and business, as defined by the Decree of the Council of Ministries. The Council of Ministers made a change to the draft secondary legislation for the ASPA by reducing the number of its steering board members from 12 to 9 , which means also a reduction of costs for the functioning of this School and by not including in this board a foreign expert, which was objected when the Department of Public Administration organized consultative meetings with stakeholders of public administration in December 2013 before submitting the final version of the secondary legislation to the Council of Ministers for final consideration and eventual approval. ${ }^{17}$

In determining the selection and vocational training policies, ASPA is obliged to co-operate with the DoPA. The ASPA's director should be appointed and dismissed in accordance with the criteria and rules established for members of the Top-Level Management Corps (TMC). By way of exception, ASPA-s Director is appointed by the Council of Ministers, upon the proposal of the Minister of Interior, until the new CSL becomes effective. The ASPA has a duty to provide vocational training as follows:

a) Thorough in-depth vocational training program, for the candidates of TMC;

b) Continuous vocational training program of civil servants of all categories, as well as any other individual outside this service. Its students will be selected from civil society, business, and individuals outside the civil service, are obliged to pay a fee to attend training programs of the ASPA. ${ }^{18}$

Meanwhile, the Council of Ministers during the month of March 2014 has approved a decision for the further regulation of the steering board of the ASPA. ${ }^{19}$ It has been published in the Official Journal, which means that it is effective from the publication date. It should be mentioned that the approved version of the Council of Minister's Decision differs from the draft version which provided that the Albanian School of Public Administration (ASPA) should appoint two representatives to the National Permanent Commission for the selection of the employees to the Corps of High Level

\footnotetext{
${ }^{13}$ Council of Ministers' Decision no.220, dated 13.02.2013, "On the establishment and functioning of the Albanian School of Public Administration and training of public administration employees"

14 Council of Ministers' Decision no. 1017, dated 18.9.2009, "On the approval of the Cross-cutting Strategy for the Public Administration Reform 2009-1013", in the framework of the National Strategy on Development and Integration"

${ }^{15}$ Article 8, Law no. 152/2013, dated 30 May 2013, "On civil servant"

${ }^{16}$ The Training Institute for Public Administration created by the Civil Service Law of 1999 did not have such a large mission; it offered training only for State administration employees, not outsiders from the private sector.

17 The authors have participated in the consultative meeting organized by the Department of Public Administration in December 2013 with the stakeholders of public administration and civil service.

${ }^{18}$ Article 9, Law no.152/2013, dated 30 May 2013, "On civil servant"

${ }_{19}$ Council of Ministers Decision no,138, dated 12 March 2014, "On the rules for the organization and functioning of the Albanian School of Public Administration and training of civil servants"
} 
Civil Servants (TMC), and one of these persons is a foreign expert. ${ }^{20}$ But this draft decision did not provide for the criteria the foreign expert selected by the ASPA should fulfill and one this should have been "good command of the Albanian language" and/or since this person is a foreign citizen, whether he has been provided with work permission in Albania. Moreover, the 2-year mandate of the National Permanent Commission might not match with the period of time the foreign expert stays in Albania, which would mean that the ASPA should appoint another foreign expert to this Commission. In addition, the ASPA might have been in difficulty to create a pool of foreign experts that qualify to become members of the National Permanent Commission for the selection of the employees to the Corps of High Level Civil Servants. What would happen if ASPA received no applications from foreign experts? These might have been some of the reasons why the approved and final version of the Council of Ministers Decision on the formation, duties and functioning of the ASPA does not foresee the participation of a foreign expert in the steering board of this School.

\section{Training of Civil Servants in other European Countries}

The continuous and qualitative training of civil servants is considered essential in the competitive European labour context. Since the private sector is much more flexible than the public one, where civil servants are employed, the former should be composed of structures that combine efficiency with the uniform and legalistic nature of hierarchical organizations. ${ }^{21}$ Civil servants need to be equipped with an enhanced access to IT information, qualification programmes, and become more performance oriented. ${ }^{22}$ Many European States with a former communist regime after political, economic and legal system changes have introduced the civil service in their respective public administration and have paid particular attention to the qualification of civil servants. Thus, Russia in 1995 through a Presidential Decree has established the Russian Academy of Civil Service with a wide network of regional branches, which offers training courses mainly for mid and top level civil servants. From 2004, funding from the State budget of civil servants' post entry training has been increasing with overall positive impact on the quality and results of training programmes. ${ }^{23}$ Similarly, the Czech Republic established in June 2001, an Institute of Public Administration, as a structure affiliated to the Office of the Government in order to provide training for the employees of the central government agencies. ${ }^{24}$ Training institutions or schools of public administration commonly and traditionally exist in many EU States such as in Italy - Scuola Superiore della Pubblica Amministrazione (Higher School of Public Administration) ${ }^{25}$, in France - Ecole nationale d'administration ENA (National School of Administration) with the specific mission of providing qualified and tailored training to civil servants of different levels and categories. ${ }^{26}$ Training of civil servants, in view of the human motivation theory of Maslow, helps them to reach self-fulfillment, capability and adequacy of being useful and necessary in the world. ${ }^{27}$

\section{Conclusions}

The new civil service law aims at specifying some blurred provisions of the civil service law of 1999, such as the effects of a Civil Service Commission's decision and at differently regulating certain aspects of the civil service law of 1999 proven to be either costly for the State budget such as one vacancy one competition procedure or subjective such as the selection of the winner of a competition procedure by the immediate superior of the future civil servant, not necessarily the first ranked in a competition procedure.

A positive novelty of the new civil service law is the establishment of the Albanian School of Public Administration, not only because by establishing this School the Albanian government fulfilled an objective of the Cross-cutting Strategy

\footnotetext{
20 Point 2, letter 'b' of the draft Council of Ministers Decision for the establishment and functioning of the ASPA published for several months since December 2013 on the web page of the Department of Public Administration www.pad.gov.al under the link 'të reja' (news)

${ }^{21}$ Pierre Peters, Handbook of Public Administration, 2nd edition, SAGE Publications, 2003, page 6

${ }^{22}$ Christoph Demmke and Timo Moilanen, Civil Services in the EU of 27 - Reform outcomes and the future of the civil service, Peter Lang Publication, Frankfurt, 2010Page 248

${ }^{23}$ Alexander Kotchegura, Civil Service Reform in Post-Communist Countries, The case of the Russian Federation and the Czech Republic, Leiden University Press, 2008, ISBN 978908728 0604, Page 66

24 Ibid. page 118

${ }^{25}$ Ed. Frits M. van der Meer, Civil Service Systems in Western Europe, 2nd edition, Edward Elgar Publishing, 2011, ISBN 978184844

2436 , page 224

26 Ibid. page 193

${ }_{27}$ Jay M. Shafritz, Albert C. Hyde, Public Administration Classic Readings, International Editions, $7^{\text {th }}$ edition, Wadsworth Cengage Learning, Printed in Canada, 2012, ISBN 978111134276 0, Page 110
} 
for Reform in Public Administration (2009-2013), but because this School will offer short and long term training for civil servants of all categories and especially top level managers should first successfully complete this School in order to be appointed in high level civil service positions.

Albania is among those Balkan states that are on the path to integration into the large European family. Its efforts for the institutionalization of the co-operation with the EU were successfully accomplished in June 2006 when a Stabilization Association Agreement was signed in Luxembourg. This Agreement is of particular importance for Albania in order to attain the status of the candidate country. It entered into force on 1 April 2009, thus, after three years from its signature, which means that Albania should consider the acceleration of its efforts for its proper and full implementation.

The SAA agreement is based on the respect of democratic principles and of human rights, respect for the principles of the international law, rule of law, and the principles of the market economy as enshrined and proclaimed in some key international documents such as the Universal Declaration of Human Rights, European Convention of Human Rights and in the Helsinki Final Act. ${ }^{28}$ Under Title VIII of the SAA "Policies of co-operation", the Article 111 is dedicated to the public administration. ${ }^{29}$ This specific provision provides for the obligation of Albania to establish an effective and responsible public administration which seeks to implement the rule of law principles. Thus, the bilateral co-operation between the EU and Albania is based and focused on the transparent and impartial recruitment procedures, management of human resources, and career development in the public services sector both at the central and local administration levels. ${ }^{30} \mathrm{In}$ fact, the signature of the SAA is only the first step for the comprehensive reform of the Albanian public administration with the sole goal of attaining the standards set forth through the principles of the European administrative space. This implies the inclusion of professional civil servants, who guarantee the independence, integrity, transparence and the implementation of the principle of service toward the public. On the other hand, this obligation means that the Albanian State should strive and guarantee the rights of civil servants as stipulated in the relevant legislation, including the right to be trained, by putting in place the necessary mechanisms for the realization of such purpose. Proactively responding to the Article 111 of the SAA the Albanian Council of Ministers approved in 2008 the Cross Cutting Strategy for the Reform of Public Administration 2009-2013, as part of the National Strategy for Development and Integration. ${ }^{31}$ Currently, among the priorities of Albania is the strengthening of public administration and the civil service to be able to afford the integration challenges ahead by correctly implementing the legislation on public administration and civil service. 32

While the new civil service law was drafted with international support, it can unfortunately not be seen as a directly applicable piece of legislation, because most of the implementation of this new law will, to a considerable extend depend on the secondary legislation which has been drafted and approved as of 1 April 2014, including the secondary legislation for the functioning of the Albanian School of Public Administration. Since the secondary legislation for the organization and functioning of t he Albanian School of Public Administration has been approved last month, the relevant steering structures should be swiftly established and the necessary personnel of this School should be again swifty hired, the training curricula for various categories of civil servants should be drafted and approves so that this School starts to function as soon as possible. In addition, its proper functioning is also linked to the long term qualification of Corps of High Level Civil Servants (TMC), who should succesfully pass the training at this School in order to preserve their job position as High Level Civil Servants. Therefore, it remains to be seen whether the new civil service law and the pertaining secondary legislation will prove to be more effective than the one of 1999, with regard also to the specialized and qualitative training provided to civil servants of various categories in the State administrative of central or local levels.

\section{Bibliography}

Alexander Kotchegura, Civil Service Reform in Post-Communist Countries, The case of the Russian Federation and the Czech Republic, Leiden University Press, 2008, ISBN 9789087280604

Christoph Demmke and Timo Moilanen, Civil Services in the EU of 27 - Reform outcomes and the future of the civil service, Peter Lang Publication, Frankfurt, 2010, ISBN 978-3-631-60466-3

Ed. Frits M. van der Meer, Civil Service Systems in Western Europe, 2nd edition, Edward Elgar Publishing, 2011, ISBN 978184844 2436

\footnotetext{
${ }^{28}$ Article 2 of the SAA, accessible at http://www.mie.gov.al/

${ }^{29}$ Article 111 of the SAA

$30 \mathrm{lbid}$

${ }^{31}$ Accessible at http://www.mie.gov.al/

32 Strategjia Kombëtare për Zhvillim dhe Integrim 2007-2013 (Cross-cutting Strategy for Development and Integration), page 16, accessible at $h$ ttp://km.gov.al/?fq=brenda\&m=shfaqart\&aid=77
} 
Jay M. Shafritz, Albert C. Hyde, Public Administration Classic Readings, International Editions, 7th edition, Wadsworth Cengage Learning, Printed in Canada, 2012, ISBN 9781111342760

Pierre Peters, Handbook of Public Administration, 2nd edition, SAGE Publications, 2003

Council of Ministers' Decision no.315, dated 23 June 2000, "On the establishment and functioning of the Training Institute for Public Administration"

Council of Ministers Decision no,138, dated 12 March 2014, "On the rules for the organization and functioning of the Albanian School of Public Administration and training of civil servants"Law no.8417, dated 21 October 1998 "Constitution of the Republic of Albania"

Law no.8549, dated 11 November 1999, "On civil servant's status"

Law no.152/2013, dated 30 May 2013, "On civil servant" 2008 Progress Report on Albania - chapter on "Public Administration", accessible at www.mie.gov.al

Council of Ministers' Decision no.315, dated 23 June 2000 "On the establishment and functioning of the Training Institute of Public Administration and training of civil servants"

Report of the Council of Europe in Albania "The National Assessment of Local Government Units' Capacities to Implement the New Law "On Civil Servant", September 2013

Strategjia Kombëtare për Zhvillim dhe Integrim 2007-2013 (Cross-cutting Strategy for Development and Integration), accessible at http://km.gov.al/?fq=brenda\&m=shfaqart\&aid=77

Stabilisation and Association Agreement between the State of Albania and the European Union, 2006, accessible at www.mie.gov.al 